\title{
MASONRY IN PARALLEL. A KNOWLEDGE BASED STRATEGY POST CENTRAL ITALY EARTHQUAKE 2016
}

\author{
C. Braucher ${ }^{1}$, E. Currà ${ }^{1, *}$ \\ ${ }^{1}$ Università "La Sapienza” di Roma, Via Eudossiana 18, Rome, Italy - (chiara.braucher, edoardo.curra)@uniroma1.it
}

Commission II - WG II/8

KEY WORDS: Masonry, Central Italy Earthquake, Classification, Vernacular techniques, Field research

\begin{abstract}
:
This research aims to propose a classification of masonry typologies in Central Italy after the earthquakes that in 2016 involved about 120 municipalities. This territory, since several decades, presents high fragility features due to the depopulation process that increase the vulnerability and risk degree. This condition affects even the maintenance practices of traditional buildings by the inhabitants and the extraordinary post-traumatic situation acts as an accelerating factor of the abandonment. In this article we will explain deeply the first part of the research, focusing in particular on methods and tools that were defined and used to carry out this study. The research highlights the need of a specific comparative tool for masonry facades classification. This was elaborated through the comparison of existed bibliography as the EMS-98, the Aedes schedules and the local classification by Umbria Region and the De Meo book. The result then is the production of another synoptic map that would simplifies the correlation between different approaches to classification and the censed facades. Moreover, it was elaborated a second synoptic map moving from the analyses of many survey forms already discuss in literature. The result of this comparison is a new survey form to carry out the field research on vernacular masonry buildings. This new form focuses on the characteristics of the buildings that the research aims to study in Central Italy. The two tools that are illustrate in the following paper were applied on one hundred survey of masonry buildings carried out during August 2018. The last part of this paper proposes a statistical analysis of the results of the field research.
\end{abstract}

\section{INTRODUCTION AND METHODOLOGY}

The seismic events that in 2016 hit a large area of the Apennine Mountains in Central Italy, concerned about $8000 \mathrm{~km} 2$ of territory, including 138 municipalities in 4 different regions: Marche, Umbria, Lazio and Abruzzo (Ingv.it). An astonishing amount of contemporary and historical buildings were damaged during these events (Hofer et al. 2018). For this reason, during the emergency phase, the technicians involved filled out 219.061 Aedes forms (Protezione Civile, 2010) and Fast forms. Thus $30 \%$ of the buildings resulted in deeply affected and condemned. This earthquake hardly affected the daily life of 600.000 inhabitants of the Central Apennine Mountains (Ingv.it). The three quakes that afflicted this territory are coherent for intensity and location with the seismic history of this area (Baratta 1901). The quakes took place between August 2016 and January 2017 (Sorrentino, et al., 2018).

The Central Apennine Mountains was the most heavily affected area by the 2016-2017 earthquakes (Liberatore et al., 2019). These mountain areas are mostly populated by small villages that, for several decades, have been characterized by a long depopulation process. The earthquake has been a factor of the acceleration of this already enacted process.

In the long term, this has had severe consequences also on historic buildings, while traditional heritage has been gradually abandoned during the last decades. The decrease in population caused a lack of maintenance (Ferrigni, 2015), contributing to increasing the already high condition of vulnerability proper of these types of buildings (Alexander, 1991).
The following paragraphs propose a review of existing bibliography about masonry classification in order to define a synoptic map, starting from the contents of EMS-98 (Giovinazzi, Lagomarsino, 2004) and NTC, Aedes form for damage survey (Protezione Civile 2010), Umbria Region restoration manual (Regione Umbria, 2015), and De Meo monography (De Meo, 2006).

The second phase of this research regards the selection of different forms for surveying masonry buildings and the analysis of the criteria that they use. The aim is to define a unique form that highlights the value of the information that we can gain with a direct survey. Materials, structural components, and their relations are the primary object in this form with a constructive approach (Aguilar, et al., 2015). In the second step, this form could be improved with numerical evaluation. This part of the research also uses the method of the synoptic map to analyze existing literature. As it can be noticed, synoptic maps are a useful tool for analyzing and summarizing, which also helps evaluate what kind of criteria are essential to examine in our specific case. This tool helps us to connect the quantitative approach of codes to a typological and constructive approach (Giuffrè, 1991).The development of the relationship between these approaches allows us to move towards an interdisciplinary attitude, to annihilate sectoral barriers, ultimately aiming to reach better results in research and projects. Finally, the field research follows the elaboration of the form. The campaign included 100 surveys in four minor municipalities in the area of Alta Valle del Tronto. The re-elaboration of the data collected during the field research correlated the geometrical, constitutive, and geographical features of the studied masonry buildings statistically. These results confirm the importance of elaborating detailed manuals that describe the masonry heritage of small areas.

\footnotetext{
* Corresponding author
} 


\section{ELABORATION OF A SYNOPTIC MAP ON MASONRY FACADES}

A summarization of the most used methods of cataloging, found in the literature, requests to highlight the criteria used for each classification. Then, the different catalogings are put in parallel, to find common and divergent characteristics, a comparative tool to analyze facades in order to develop an interdisciplinary approach.

This synoptic map (Figure 1) allows us to summarize and compare some of the categorizations that can be found in the literature. These are connected to different disciplinary areas, such as structural, architectural, and restoration. The chosen references were la EMS-98 (Giovinazzi, Lagomarsino, 2004), the 2018 NTC, the Aedes schedule for damage survey, the Umbria Region restoration manual (Regione Umbria, 2015), and the De Meo monography (De Meo, 2006).

The categorizations chosen as the first reference are codes EMS-98 and NTC. These provide resistance values for different masonry typologies. These are the most schematic amongst the studied ones. They mainly refer to the type of stone used and its shape. Of course, these features are the starting point for this work because they are common to all the other analyzed classifications.

Many more characteristics emerged from the comparison of these codes with more detailed classifications that aimed to study traditional and local masonry techniques: such as the technical manual of Regione Umbria and the work on the Sabina area by M. De Meo. While studying small areas, geographical and cultural diversity stand out, and the level of detail increases.

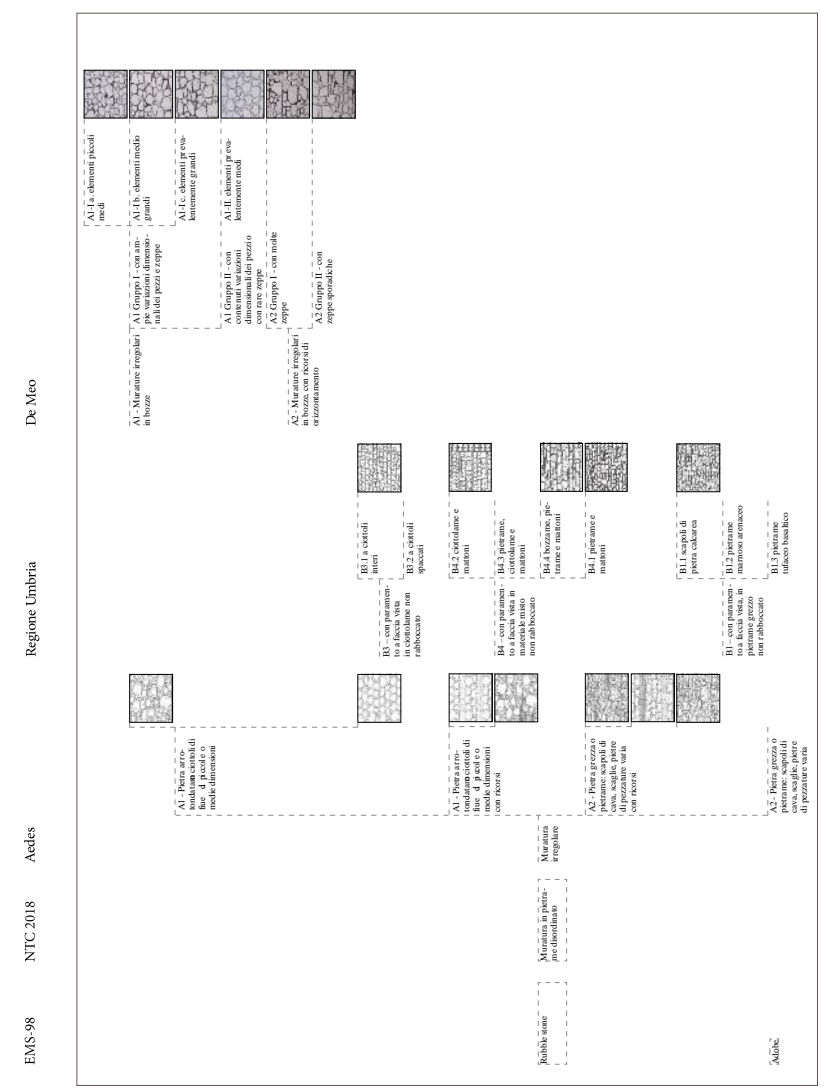

Figure 1. Synoptic map of facades.
The first feature commonly analyzed is the shape of the stones of which the facade is made of. These are classified from the least to the most regular. In fact, only the studies regarding local techniques specifically deal with dimensions and other characteristics of the stones.

Another common feature that both Aedes and Regione Umbria classify is the material of which the facade is made of, precisely, the type of stone.

De Meo's classification, instead, is more complicated because it intersects different criteria: for irregular parameters, he analyses stone dimension and the presence of zeppe, while for more regular facades, he is interested in defining the type of stones. This complex situation made it necessary to elaborate on another tool to approach the field research in order to obtain an accurate result.

\section{SURVEY FORM FROM LITERATURE REVIEW}

The identification of an adequate survey form of vernacular masonry requests an analytical review of the existing catalogings, made through a synoptic map for the comparison (Rota et al., 2011).

In the new survey form, all the features are considered, with particular focus on constructive masonry characteristics (Degli Abbati et al.,2016).

\subsection{Literature review of survey's forms}

The first reference of this analysis is the study published by ICCD (Central Institute for the Catalog and Documentation) named "Criteria for the description of masonry techniques." This study of ICCD is a literature review of different works that elaborated survey forms. This study underlines similarities and differences between the described forms, with particular reference to language, the difference between description; one of the main objectives of this work is to start the elaboration on a National Atlas of Masonry Techniques ${ }^{1}$

Thus, the contribute analyses are linked to different academic disciplines and are compared with NTC $2008^{2}$; the objective is to reach an interdisciplinary summary. The quantitative parameters of NTC are fixed as a reference and compared with each survey form and the different criteria analyzed.

So, one of the main aims is to compare each form in parallel, searching a connection in language, content, and description.

The ICCD proposes four different sections of analysis: masonry typology, defined by the shape of the stones and the regularity of the texture; mortar characteristics; transversal section and its features; restoration, and conservation intervention. At first, it analyzed the form presented in the book "Indicazioni per la Valutazione della Qualità Muraria" wroten by E. Curti, A Lemme e S. Podestà (Curti et al., 2008). In particular, chapter 3 focuses on some processes useful for the definition of masonry quality through direct survey practice.

The poll, in this case, is divided into three levels: the first connected to constitutive elements, type of stone or type of mortar, the second level is related to the texture of masonry to its regularity; the third was linked to the type of transversal section.

ICCD - Istituto Centrale per il Catalogo e la Documentazione criteri.

CS.LL.PP. (2008) - Norme tecniche per le costruzioni. Gazzetta Ufficiale della Repubblica Italiana, 29. 
Moreover, the work edited by D. Fiorani and D. Esposito in 2005, "Tecniche costruttive dell'edilizia storica: conoscere per conservare" proposes a collection of contributes and most of them are related to the analyses of historical masonry buildings (Fiorani, Esposito, 2005). This volume includes the work of L. Binda, "Studio della vulnerabilità degli edifici dei centri storici in zona sismica" (Binda et al., 2005), and the one of E. Saisi "Rilievo e studio del comportamento di sezioni murarie: il problema delle murature in pietra" (Saisi, 2005).

Fiorani explains the necessity to obtain, during the field research, a fast and complete analyses starting from masonry facades and not from 3D knowledge; this is very difficult if masonry are not already heavily damaged ${ }^{3}$.

The Manuale delle murature storiche, edited by A. Borri C. Donà and A. De Maria, moves from Giuffrè studies concerning regola dell'arte and the real heterogeneity of masonry buildings and develops another cataloging form ${ }^{4}$.

Referring to the contributes of A. Borri Criteri qualitativi per definire la sicurezza strutturale nell'analisi della qualità muraria, and of A. Borri e De Maria, IQM (Indice di Qualità Muraria): definizione e linee guida per la compilazione della scheda, a form to count an index of masonry quality is developed. In this work, they explain how to do these analyses $^{5}$ (Borri, De Maria, 2005).

Here the main investigated parameters: the presence of transversal connections, the quality of mortar, the shape and the dimension of elements, and the wall regularity (Borri, 2011)

The work of Cecchi moves, instead, from a different academic field, it is titled Roma archaeologia: interventi per la tutela e la fruizione del patrimonio archeologico (Cecchi, 2011). He approaches the study from a historicalstratigraphic analysis, understanding the importance of dealing with this theme in an interdisciplinary way. For this reason, he includes in the cognitive process, even structural

\footnotetext{
“...uno sforzo di sintesi necessario alla definizione di un quadro complessivo che porti a privilegiare gli aspetti più immediatamente percettibili d'una struttura muraria, favorendo, ad esempio, la lettura dei paramenti rispetto ad una visione tridimensionale delle pareti, il confronto fra murature regolari piuttosto che irregolari (per le quali è necessario un maggiore affinamento della lettura analitica dei componenti)" extract from D. Fiorani, Murature medievali in Italia, spunti di riflessione da una ricerca, in D. Fiorani, D. Esposito (a cura di), Tecniche costruttive dell'edilizia storica: conoscere per conservare, Viella, 2005, Introduzione pp. 35.

4 "...è l'insieme di tutti quegli accorgimenti costruttivi che, se eseguiti durante la costruzione di un muro, garantiscono un buon comportamento e assicurano la compattezza e il monolitismo dello stesso" extract from A. Borri, G. Cangi, A. De Maria, C. Donà, Criteri qualitativi per definire la sicurezza strutturale nell'analisi della qualità muraria: ipotesi di base, in AA.VV. Manuale delle murature storiche, Direttore scientifico A. Borri, a cura di C. Donà, A. De Maria, D.E.I., Tipografia del Genio Civile, 2011, p. 238.

5 "Nella valutazione dell'IQM entrano in gioco alcuni parametri caratteristici della corretta ed efficace messa in opera della muratura: i cosiddetti parametri della "regola dell'arte". Tramite l'osservazione della muratura viene infatti valutato il grado di rispetto di ogni parametro della regola dell'arte sulla base di alcune regole che saranno definite nel seguito." A. Borri, A. De Maria. "Linee guida per la compilazione della scheda di valutazione dell'IQM. "Rete dei Laboratori Universitari di Ingegneria Sismica" (RELUIS). Progetto esecutivo 2008 (2005).
}

and conservative evaluations. The volume includes several contributions, divided on the base of the components of the building. In the number, we find the Camporeale's one which proposes a survey form (Camporeale, 2011), structured in several parts that deal with themes such as the used material, shape, and dimensions of the block, the finishing touch and the type of mortar.

A first consideration is that the works concerning the archaeology of architecture show an increase of the details that are taken into consideration, making stratigraphic and archeological analyses: the arrangement of stones, the connection between stones and the manufacturing process. This methodological approach aims to retrace the history and transformations of buildings as linear in time.

Also, Dogliani, Mirabelli, and Roberti developed an analysis, Venezia: forme della costruzione, forme del dissesto (Doglioni, Mirabelli, 2011), that through the signs on masonry to retrace the constructive and transformative process. The parameters considered by this work are the type of element, dimension, and shape of the blocks, the texture of masonry, mortar characteristics, the finishing touch, and stratigraphy.

In a brief state of the art shows that most of the works have some criteria in common, while others adopt specific ones related to different academic fields. The academic fields that deal with this matter are many, the first aim of this research is to develop a method to analyse them and to understand which parameters are more useful to study a specific case study. Furthermore, this analysis highlights lexical problems due to the fact that many academic fields work on masonry buildings.

\subsection{Synoptic map for survey's forms}

A second tool for the analysis is the elaboration of a synoptic map (Figure 2). The forms are disposed from left to right from the less detailed, characterized by a structural approach (as codes), to the ones that have a constructive approach (Giuffrè, 1991) and at least to the one with an approach connected to restoration and archeology of architecture (Camporeale, 2011). The comparison in parallel of these forms highlights the lexical differences together with the frequency of the analyzed parameters. The synoptic map of the survey forms is divided into the three main groups to analyze: facades, that regard blocks shape, dimensions, and texture of masonry, mortar, its quality, and transversal section.

The frequency of the parameters of the synoptic map allows us to understand which criteria are more investigated than others and so which are more significant. Each form investigates specific data, and the selection of these depends on the aim of the form. Of course, the parameters connected to the rule of thumb are manlily studied by all the authors.

The necessity to define a specific form for this field research is highlighted by these literature reviews among the topics of classification and survey forms discussed in the previous paragraphs. To elaborate this tool at first, the frequency of the parameters was analyzed. This evaluation permitted to connect the literature review and the form we developed for the Central Apennine area. 


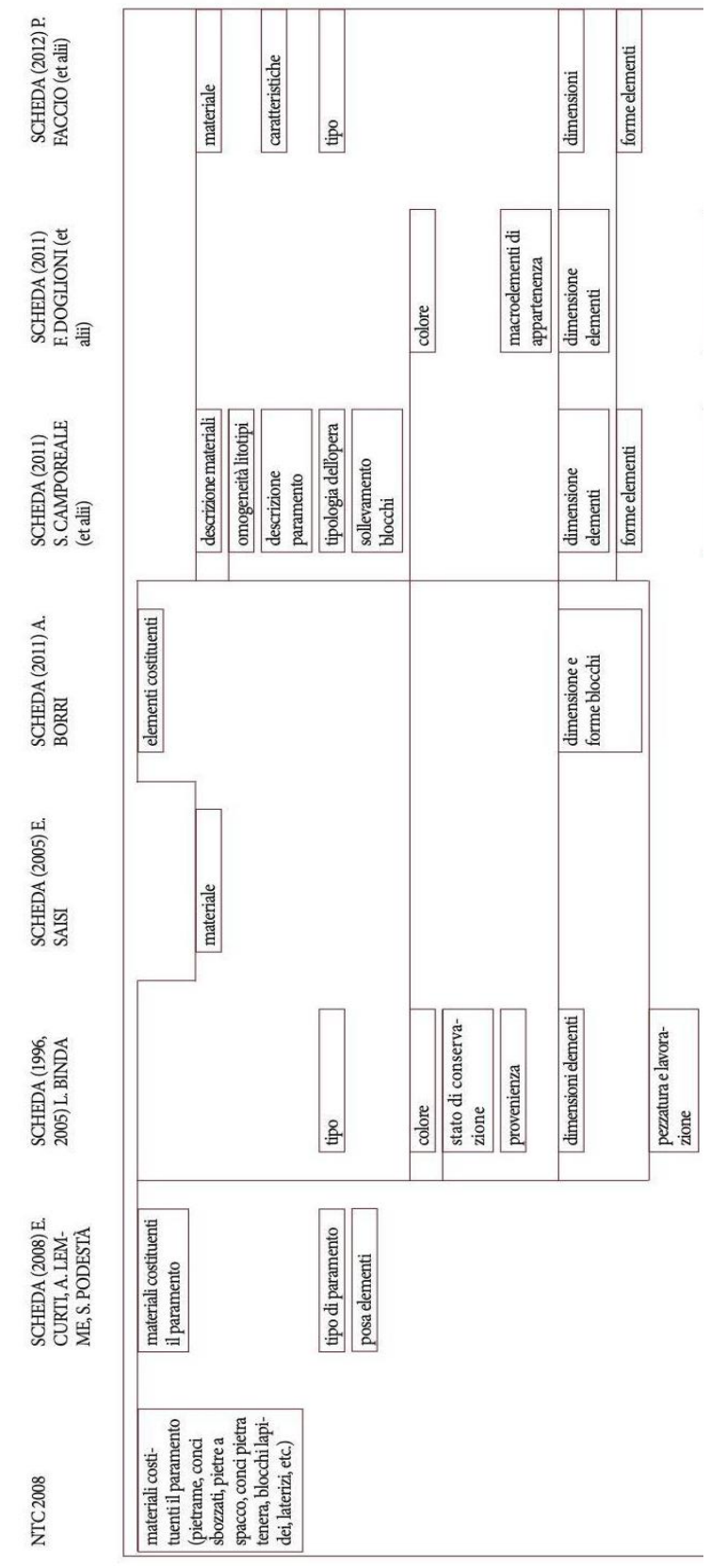

Figure 2. Synoptic map of survey forms.

\subsection{Survey form elaboration}

The definitive survey form, moving from the analyzed bibliography, was elaborated considering the most recurrent and useful data highlighted by the synoptic map and its uses. The form sets different analytical sections, from the localization to constructive elements, mortar, facade texture, and the transversal section on the wall.

The form proposed in this article (Figure 3) was structured to be completely online, so the first section has two parts: one localizes the survey geographically, the other is used to add a multimedia file on the form to complete the survey.

The first section, as we previously discussed, allows us to localize the survey with GPS geographically, the region, the province, the municipality and locality (the name of the village). It is also necessary to include the date of the survey.
The following section allows us to study the constructive element: shape, dimensions, homogeneity of dimensions, the constitutive material, the color of stones, the homogeneity of the material, and lastly, the conservation state of the constitutive elements is required. The third section regards the analyses of the mortar, and the thickness and conservation state are studied.

The following one wants the operator to describe the texture of the whole facade. The fifth section regards the transversal section of the wall: its thickness and connections. Furthermore, as reported before, it is possible to add multimedia files and complete the survey.

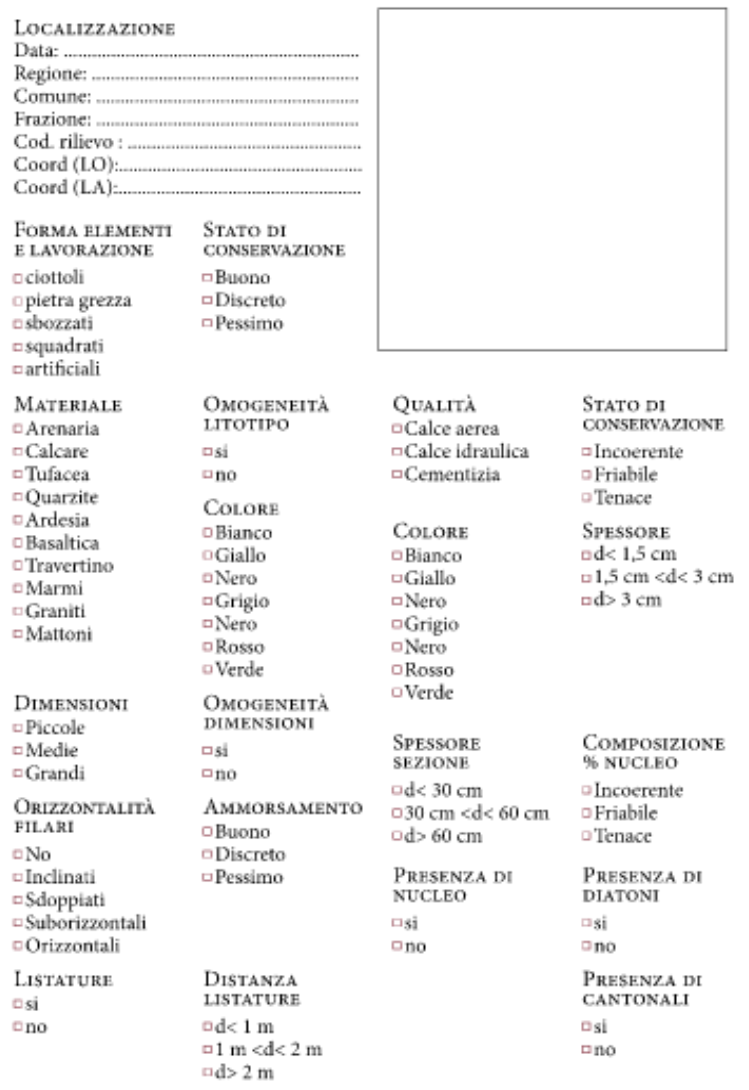

Figure 3. Survey form.

\section{ANALYSES AND RESULTS FROM FIELD RESEARCH}

The field research started in June 2018 and ended in September. This was divided in phases; the first phase between June and July had the objective to reach a general knowledge regarding the main technical characteristics of the huge area that the earthquakes of 2016-2017 hit. Following this initial study, it was possible to elaborate and outline which areas are characterized by a similar masonry and which instead are extremely different (Braucher, Currà, 2018).

This first step provided the basic knowledge to proceed with a more detailed analyses of a smaller area characterized by the same technical typology. For this reason, four similar municipality were chosen; mainly characterized by stone masonry and strongly involved by the earthquakes of 2016: Amatrice, Accumoli in Lazio region and Arquata del Tronto and Montegallo in Marche region. 


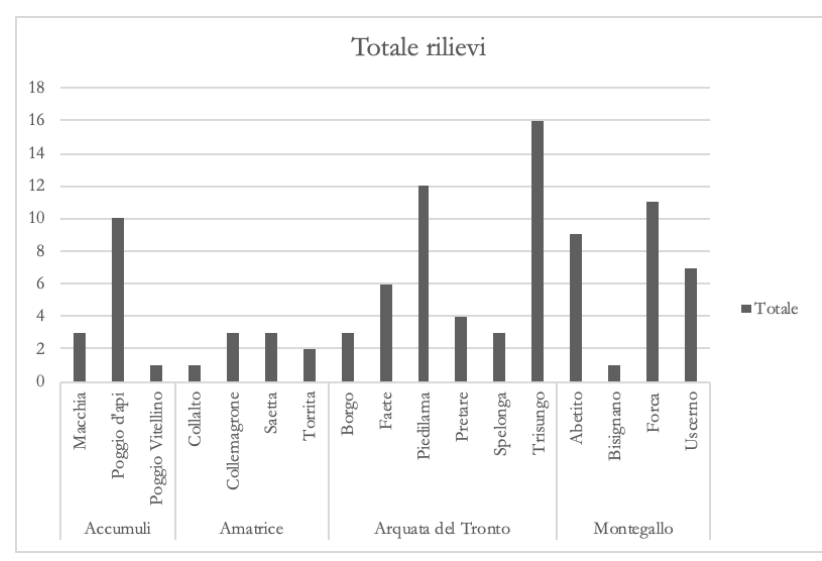

Figure 4. Location of survey.

About one hundred surveys were carried out in six different municipalities: 14 at Accumoli, 9 at Amatrice, 44 at Arquata del Tronto, 28 at Montegallo, and overall 3 between Roccafluzione e Piane Vecchie (Figure 4). These last municipalities were not considered in the following analyses because the sample of surveys were not significant.

Moving forward in the analyses of the shape of the stones (Figure 5) we can see that, in general, the elements are well-cut. Between $43 \%$ and $35 \%$ are rubble stones, $13 \%$ squared and only the $7 \%$ was characterized by rounded stones. Connecting this data to the municipalities it is possible to notice that for Accumoli and Amatrice the survey facade presents a well-cut type of stone, Arquata presents a majority of rubble stone masonry and Montegallo is, instead, characterized by squared stones.

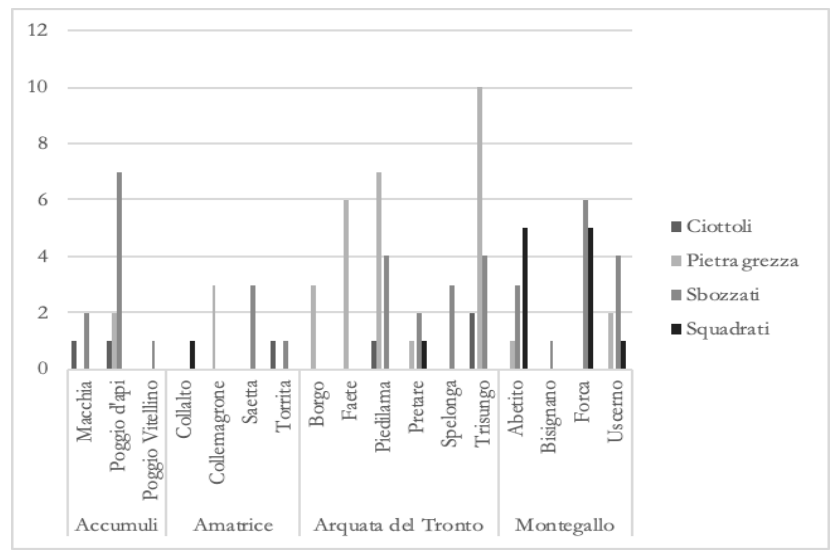

Figure 5. Relation between location and shape.

Is possible to notice that mainly, the surveyed facades do not have stones shaped with a bad quality, on the contrary it was evidenced that there is a prevalence of well-shaped stones considering the surveyed masonries.

Considering the block dimensions (Figure 6) of the analyzed facades it is possible to evidence that: 81 are characterized by medium dimensions blocks on a total of 95 surveys that we are now analyzing, the surveyed masonry characterized by small blocks are concentrated in the municipality of Arquata del Tronto. Instead, the structures characterized by big blocks are 3 and these are concentrated in the Montegallo municipality. In figure 7 we can notice that there is a direct connection between the degree of workmanship of blocks and the dimensions of them.

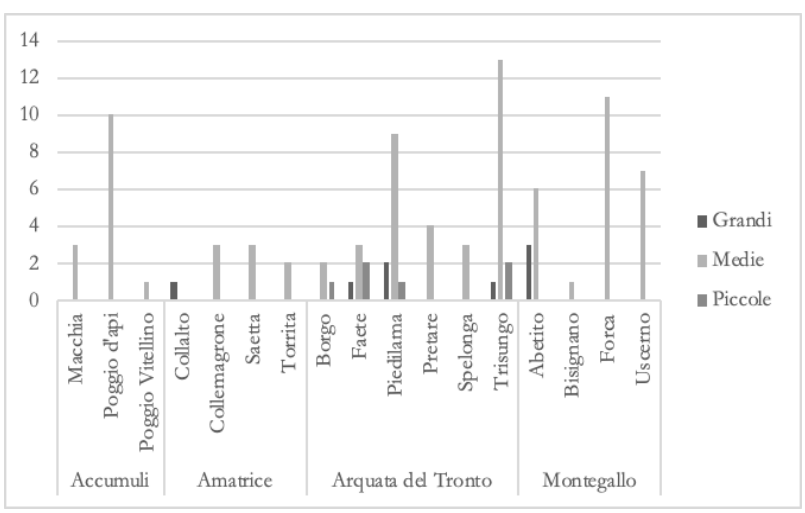

Figure 6. Relation between location and dimension of the block.

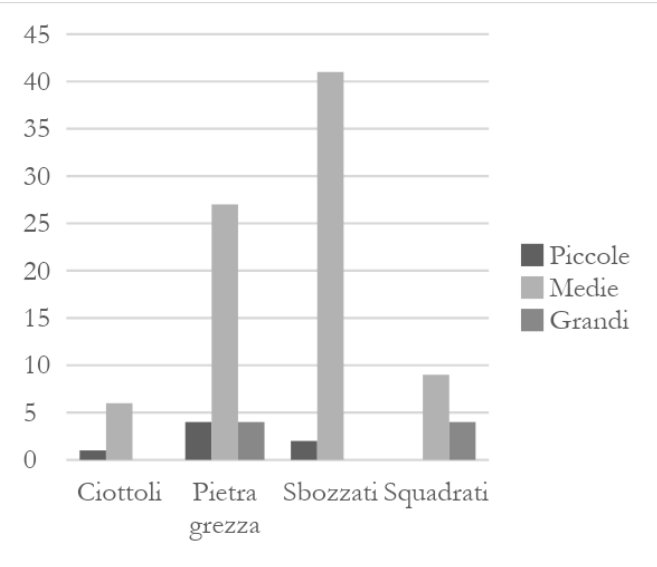

Figure 7. Relation between dimension and shape.

Another parameter that was investigated to understand the degree of regularity of masonry facades was the homogeneity of the dimension in the same survey (Figure 8). Is possible to notice from figure 8 that small blocks used are not homogenous in terms of dimensions; instead for surveys characterized by big stones the homogeneity of the texture increases.

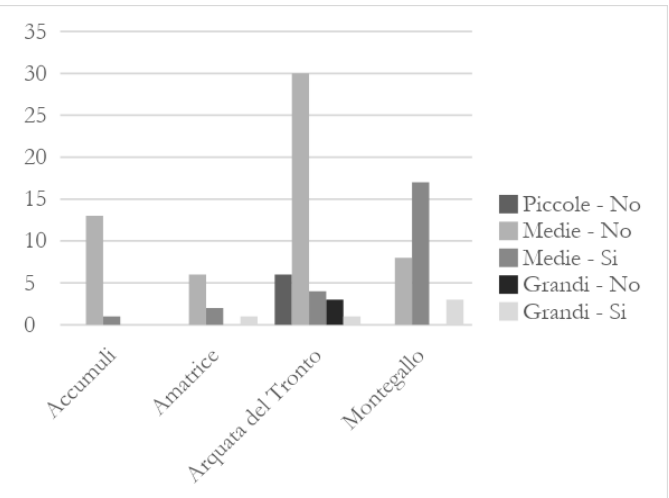

Figure 8. Relation between location and dimension and homogeneity of blocks.

The last factor that aims to investigate the facade elements and their texture is the horizontality of mortar joints. As the other factors, higher the horizontality of mortar joints, the higher is the homogeneity of block dimensions, and the dimensions of blocks is bigger as well (Figure 9). All these parameters are synonymous of the taxture's characteristics. The geographic allocation is similar to the other factors. 


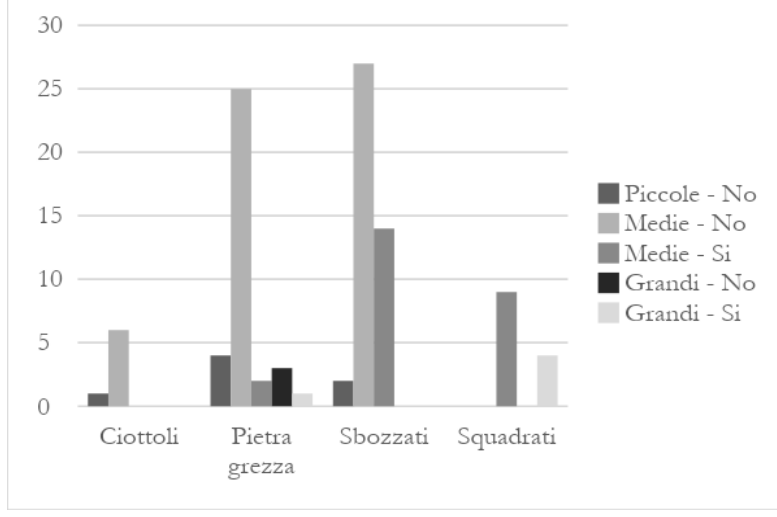

Figure 9. Relation between

blocks shape, dimensions and regularity.

The following section of the survey form considers the analyses of the parameter in its entirety. At first, we can put in relation blocks dimensions and the degree of ammorsamento characteristic that usually have benefits for the structure.

The relation between ammorsamento and all the other regularity features is the same of the previous factors, bigger blocks, more regular dimensions, homogeneity on joints design (Figure 10), as well the degree of regular texture increases with the increase of the degree of ammorsamento.

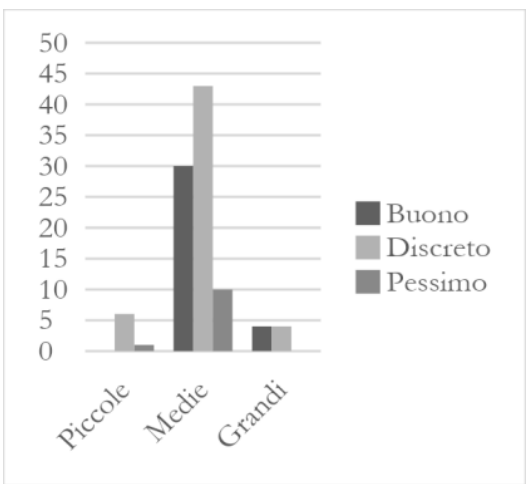

Figure 10. Relation between

ammorsamento and stones dimensions.

In possible to notice that 64 surveys present good angle connection due to well squared blocks (Figure 11); this feature is not present in 31 of surveyed facade, mainly the ones characterized by big stones (Figure 12). This is a characteristic that underlines the knowledge of the rule of thumb that is typical of this territory.

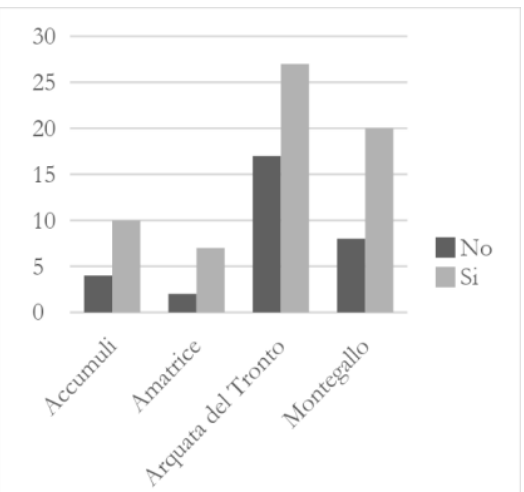

Figure 11. Relation between cantonali and suvey's location.

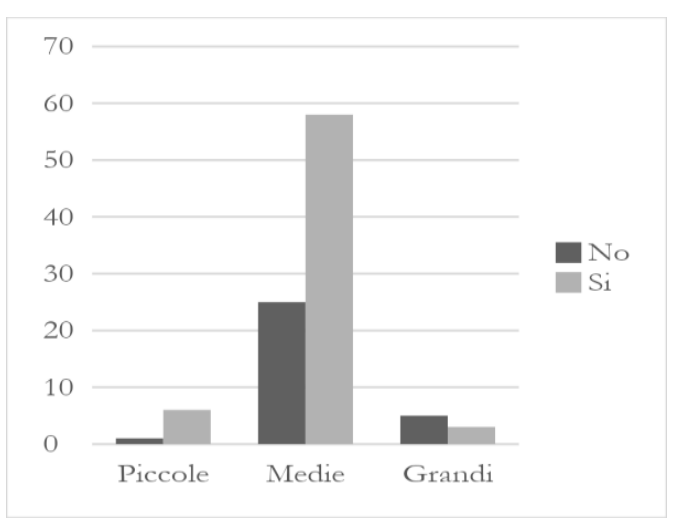

Figure 12. Relation between dimensions and cantonali.

\section{CONCLUSIONS}

The starting point of the current study has been the posttraumatic situation that involved Central Apennines starting from 2016. Moving from the well-known status of high fragility of the built heritage, the first objective of this work was to classify a bibliography review among masonry types from different levels of study. These were systematized and split in a synoptic map. A similar method was used to analyze some of the survey forms collected from literature, as well, a synoptic map was elaborated to split in parallel the features of the survey form and to define a new survey form for the field research of this work. This method permitted to evaluate a significant number of elements and to connect them; it helped us to understand deeper the features that were investigated during the survey research on masonry buildings.

The field research at the moment consists of the evaluation of the survey form used and on a statistical comparison between regularity features of masonry facade.

The variety of masonry typologies and literature reference in Italy, as in many other countries, highlights the necessity not to define a unique reference table in which strictly find a position for each survey possible. The objective is to define a methodology that can help us to systematize literature and the work of authors that studied an area. An example is the synoptic map of the facade, defined at par. 2 of this article. This methodology was applied even to the definition of a survey form, the synoptic map of survey forms, and the survey form we defined is a first elaboration of this instrument that, of course, needs to be deeper investigated and implemented by many other studies. In the last part of the paper, the analyses of 100 surveys take in count. The parameters considered are location, dimension and shape, homogeneity in dimension, the horizontality of the mortar joint, quality of masonry in general, and the presents of ammorsamento and cantonali.

These statistical analyses underline the rule of thumbs typical of this territory; the features that are highlighted by the surveys represent the main characteristics of the local architecture.

\section{ACKNOWLEDGMENTS}

Research Coordinator and Methodology: Edoardo Currà. Analitical researc and field research: Chiara Braucher

Paper drafting: 1 EC, 2 CB EC, 3.1 CB, 3.2 CB, 3.3 CB, 4. CB, 5. CB EC; Table and schemes elaboration: Chiara Braucher; Reviewer: Edoardo Currà. 


\section{REFERENCES}

Aguilar, R., Marques, R., Sovero, K., Martel, C., Trujillano, F., Boroschek, R., 2015. Investigations on the structural behaviour of archaeological heritage in Peru: From survey to seismic assessment. Engineering Structures, 95, p. 94-111.

Alexander, D., 1991. Natural disasters: a framework for research and teaching. Disasters, 15(3), p. 209-226.

Baratta, M., 1901. I terremoti d'Italia: saggio di storia, geografia e bibliografia sismica italiana (No. 9). Fratelli Bocca.

Binda L., Cardani G., Modena C., Saisi A.E., Valluzzi M.R., 2005 Studio della vulnerabilità degli edifici dei centri storici in zona sismica, in Tecniche costruttive dell'edilizia storica. Conoscere per conservare, a cura di D. Fiorani, D. Esposito: Viella Editore, p. $17-30$

Borri, A., De Maria, A., 2005. Linee guida per la compilazione della scheda di valutazione dell'IQM. Rete dei Laboratori Universitari di Ingegneria Sismica (RELUIS). Progetto esecutivo, 2008.

Borri A., Cangi G., De Maria A., Donà C., 2011. Criteri qualitativi per definire la sicurezza strutturale nell'analisi della qualità muraria: ipotesi di base, in AA.VV., Manuale delle murature storiche, Direttore scientifico A. Borri, a cura di C. Donà, A. De Maria, D.E.I., Tipografia del Genio Civile, p. 238.

Braucher C., Currà E., 2018. Murature in parallelo. Per un atlante sinottico nell'area del sisma del Centro Italia 2016. Negli atti del convegno Ingegno e costruzione nell'epoca della complessità, $\mathrm{p}$. 48-55. 978-88-96386-75-0

Camporeale S., 2011. Schema di Linee Guida per la conservazione delle architetture di interesse archeologico. Conoscenza, prevenzione, manutenzione, in R. CECCHI (a cura di), Roma archooologia: interventi per la tutela e la fruizione del patrimonio archeologico. Terzo rapporto, vol. Primo, Electa.

CS.LL.PP., 2008 - Norme tecniche per le costruzioni. Gazzetta Ufficiale della Repubblica Italiana, 29.

CS.LL.PP., 2018 - Aggiornamento delle Norme tecniche per le costruzioni. Gazzetta Ufficiale della Repubblica Italiana, 42.

CS.LL.PP., $2019 \quad$ - $\quad$ Istruzioni per l'applicazione dell'«Aggiornamento delle "Norme tecniche per le costruzioni"», Gazzetta Ufficiale della Repubblica Italiana, 35, p. 1-337.

Curti E., Lemme A., Podestà S., 2008. Indicazioni per la Valutazione della Qualità Muraria e redatta dal capitolo 3 del libro Sisma Molise 2002: dall'emergenza alla ricostruzione. Edifici in muratura, editato da D.E.I.

De Meo, M., 2006. Tecniche costruttive murarie medievali: la Sabina (Vol. 5). L'Erma di Bretschneider.

Degli Abbati, S., Cattari, S., Lagomarsino, S., 2016 Seismic assessment of single-block rocking elements in masonry structures. Diss. PhD Thesis. Università Degli Studi de Genova. Genova.

Doglioni F., Mirabelli Roberti G., 2011. Venezia: forme della costruzione, forme del dissesto, Cluva.
Doglioni F., Mirabelli Roberti G. Prove sperimentali speditive $e$ valutazioni di vulnerabilità delle murature, in Monumenti \& terremoti: nuove esperienze di analisi di vulnerabilità, pericolosità sismica. Risultati del programma ENEA- MIUR, p. 93-106.

Ferrigni, F., 2015. Vernacular architecture: A paradigm of the local seismic culture. Seismic Retrofitting: Learning from Vernacular Architecture, 3.

Fiorani D., 2005. Murature medievali in Italia, spunti di riflessione da una ricerca, in D. Fiorani, D. Esposito (a cura di), Tecniche costruttive dell'edilizia storica: conoscere per conservare, Viella, Introduzione p. 35.

Giovinazzi, S., Lagomarsino, S., 2004. A Macroseismic Model for the vulnerability assessment of buildings. 13th World Conference on Earthquake Engineering. Vancouver, Canada.

Giuffrè, Antonino, 1991. Letture sulla meccanica delle murature storiche.

Hofer, L., Zampieri, P., Zanini, M. A., Faleschini, F., Pellegrino, C., 2018. Seismic damage survey and empirical fragility curves for churches after the August 24, 2016 Central Italy earthquake. Soil Dynamics and Earthquake Engineering, 111, p. 98-109.

ICCD (Istituto Centrale per il Catalogo e la Documentazione) Criteri di descrizione delle tecniche murarie per la predisposizione di moduli schedografici codificati - Ricognizione bibliografica. Ministero per i Beni e le Attività Culturali.

Liberatore, D., Doglioni, C., AlShawa, O., Atzori, S., Sorrentino, L., 2019. Effects of coseismic ground vertical motion on masonry constructions damage during the 2016 Amatrice-Norcia (Central Italy) earthquakes. Soil Dynamics and Earthquake Engineering, 120, 423-435.

Protezione Civile, AeDES, 2011. Scheda Agibilità e Danno nell'Emergenza Sismica, First Level form for safety assessment, damage investigation, prompt intervention for ordinary buildings in the post-earthquake emergency.

Rota, M., Penna, A., Strobbia, C., Magenes, G., 2011. Typological seismic risk maps for Italy. Earthquake Spectra, 27(3), p. 907-926.

Regione Umbria, Repertorio dei tipi e degli elementi ricorrenti nell'edilizia tradizionale, Supplemento ordinario $n .1$ al «Bollettino Ufficiale»- Serie Generale - n. 40 del 12 agosto 2015.

Saisi A.E., 2005. Rilievo e studio del comportamento di sezioni murarie: il problema delle murature in pietra in D. Fiorani, D. Esposito (a cura di), Tecniche costruttive dell'edilizia storica: conoscere per conservare, Viella, p. 191-202.

Sorrentino, L., et al., 2018. Seismic behavior of ordinary masonry buildings during the 2016 central Italy earthquakes, Bulletin of Earthquake Engineering, p. 1-25. 